\title{
Major Structural Features and the Tectonic Evolution of the Bossangoa- Bossembele Basement, Northwestern Central African Republic
}

\author{
Mapoka Hubert $^{1,2}$, Danguene Y. Prince Emilien ${ }^{1,2}$, Jean Paul Nzenti ${ }^{*}, 2$, Biandja Jean ${ }^{1}$, \\ Kankeu Boniface ${ }^{3}$ and Suh Cheo Emmanuel ${ }^{4}$ \\ ${ }^{I}$ Department of Geology, University of Bangui, P.O. Box 908, Bangui, Central African Republic \\ ${ }^{2}$ Laboratory of Petrology and Structural Geology, Department of Earth Sciences, University of Yaoundé I, P.O. Box \\ 3412 Messa-Yaoundé, Cameroon \\ ${ }^{3}$ Institute of Mining and Geological Research, P.O. Box 4110 Yaoundé, Cameroon \\ ${ }^{4}$ Department of Geology and Environmental Science, University of Buea, P.O. Box 63, South West Province, Cameroon
}

\begin{abstract}
Planar structures (foliations and shear zones) and linear structures (lineations, fold axes) around the Bossangoa and Bossembele area (northwestern part of the Central African Republic) in the North Equatorial fold belt have been investigated and analyzed with the aim of unraveling the major structural elements and the tectonic evolution of the basement. The foliations show two major trends, an older flat-lying granulitic layering of uncertain age reworked by later, Neoproterozoic NE-SW ductile, sinistral shearing and mylonitization. The related lineation is conspicuous and corresponds to a mineral and stretching lineation. It trends $\mathrm{N} 0-30^{\circ} \mathrm{E}$ with a moderate plunge $(0-15)$ towards the north. $\mathrm{F}_{1}$ folds occur only as decimeter-sized isoclinals folds; their axial traces are roughly parallel to the lineation. The brittle phase characterized by NW-SE-trending open and partially filled fractures is younger than the mylonitization. Quartzofelsdpathic anatectic veins or planes are commonly boudinaged, and the shape of boudins rather suggests non-coaxial deformation. The mylonitic foliation with associated stretching lineation and the ductile shear zone are recognized for the first time and support a tectonic evolution in which ductile deformation was overprinted by brittle failure accompanied by the emplacement of some intrusives.
\end{abstract}

Keywords: Bossangoa and Bossembele area, Foliations, Pan-African, Ductile shear zone, Brittle tectonics, Central African Republic.

\section{INTRODUCTION}

The Bossangoa-Bossembele area (NW Central African Republic-CAR) forms part of the North Equatorial Fold Belt (NEFB) that extends from Nigeria to the CAR through Cameroon and can be correlated with the Borborema Province of NE Brazil [1]. The NEFB is affected by the Central Cameroon Shear Zone (CCSZ; [2]), which is a major lineament of the Pan-African Orogen of Central Africa. This transcontinental shear zone is a major crustal discontinuity extending from north-eastern Brazil into CAR (Fig. 1) and has been the focus of numerous investigations [3-11]. Deformation along the CCSZ is not homogeneous and is closely linked to granitoid intrusion events. Separate regions of dextral and sinistral shearing as well as zones of reversal of shear sense have been described (e.g. [12, 13]). In all these studies, the segment of the CCSZ in CAR has remained largely unstudied. The occurrence of deformed basement rocks truncated by ductile and brittle features, some of which acted as pathways for magma ascent and eruption, makes the Bossangoa-Bossembele area a suitable site for studying the evolution of the CCSZ and its

*Address correspondence to this author at the Laboratory of Petrology and Structural Geology, Department of Earth Sciences, University of Yaoundé I, P.O. Box 3412 Messa-Yaoundé, Cameroon; Tel: (237) 948564 73;

E-mail: jnzenti@uy1.uninet.cm geodynamic significance in the Pan-African NEFB in CAR. The relative timing of these deformation and magmatic events is still unclear in many parts of the CCSZ. The mapping of this area carried out during this study has revealed excellent exposures of the basement and has inspired this contribution. We show in this paper that earlier flat-lying granulitic foliations of uncertain age were reworked by Pan-African ductile sinistral shear zones, resulting in a prominent NE-SW mylonitic foliation parallel to the regional trend of the NEFB and the Sergipe Belt. This ductile event was followed by brittle deformation that produced E-W to NW-SE-trending fractures. Many of these Pan-African ductile shear zones are filled by granitic dykes and veins suggesting that the brittle event is linked to the emplacement of granitoids of Neoproterozoic age $[8,10]$.

\section{GEOLOGICAL SETTING}

The work of some authors (e.g. [14-22]) shows that the CAR can be divided in three major structural units from south to north:

1- Southern part: The Congo Craton consists of (1) micaschists and quartzites of Archean and Paleoproterozoic age [23]; (2) metabasites (amphibolites, pyroxenites of Mbomou) of Archean age (2900 Ma; [16]); (3) charnockites series and gneisses similar to those of the Congo Craton in Cameroon [18], and (4) Archean greenstones (komatiites), 


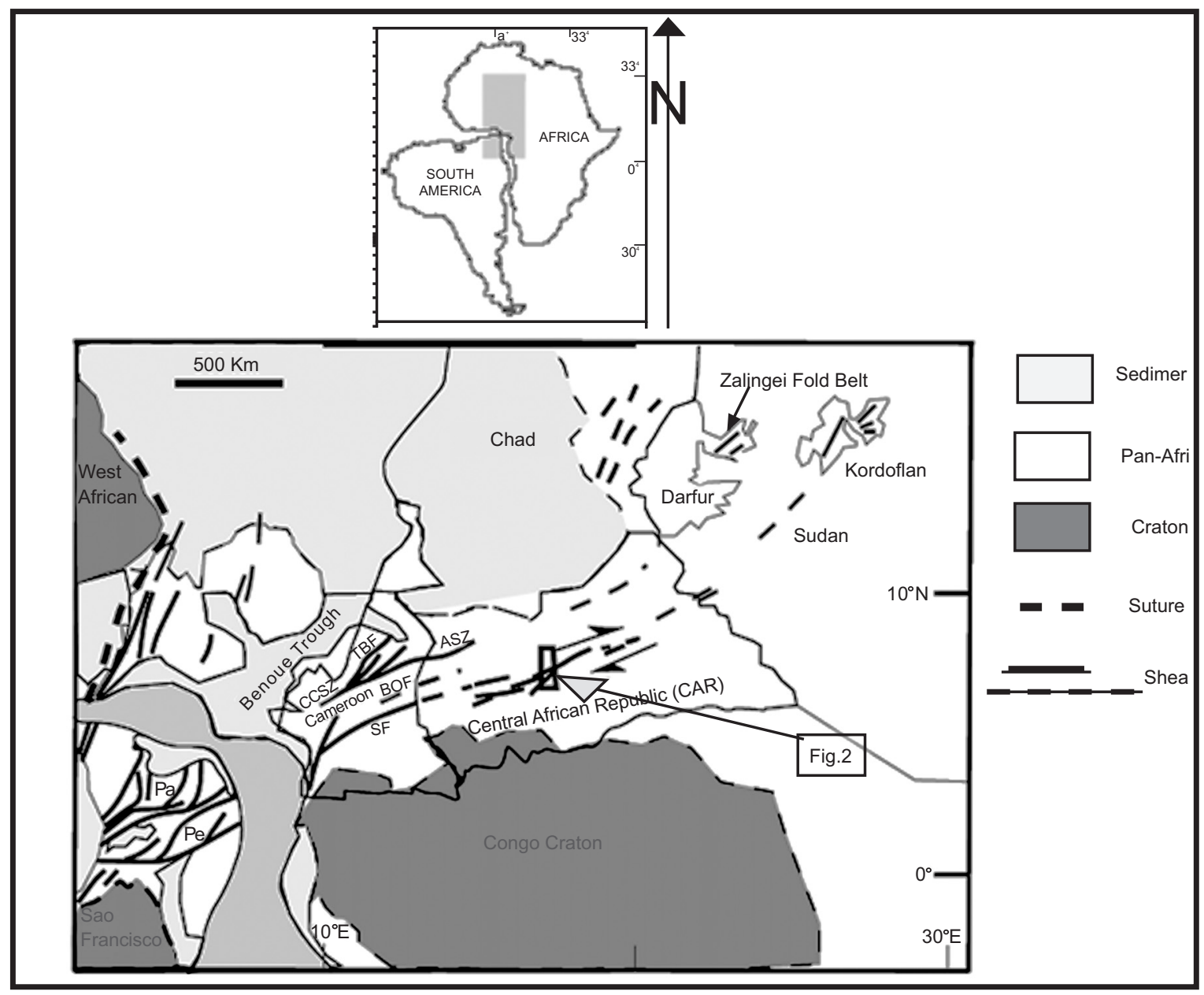

Fig. (1). Palinspatic reconstruction of Africa and NE Brazil (late-Precambrian) modified from [1]. ASZ: Adamawa shear zone (or Cameroon Central Shear Zone: CCSZ); SF: Sanaga fault; SL: Sặo Luis Craton; Pa: Patos shear zone; Pe: Pernambuco shear zone; TBF: FoumbanTibati-Banyo fault. BOF: Bétaré Oya Fault.

itabirites, greywackes, rhyodacitic tuffs and granitoids [24, 25]. (5) The central part of this domain is occupied by an intermediate rock series (2100 Ma [18]), which consists of quartzites, amphibolites and orthogneisses.

2- The intermediate domain consists of Archean gneisses, metabasites, granites and Paleoproterozoic metasedimentary rocks and migmatites. According to Rolin [22] these rocks are separated from the Neoproterozoic gneisses by a ductile shear zone.

3- The Northern part is composed of granulites, orthogneissic and granite of Neoproterozoic age $(833 \pm 66$ $\mathrm{Ma}$ [18]). It corresponds to the western extension of the PanAfrican fold belt in Cameroon. This domain is bordered in the south by a late Pan-African shear zone [26].

The Bossangoa-Bossembele area (Fig. 2) is affected in the north by a tectonic lineament more or less parallel to the Centrafricano-Tchadian border. This lineament extends from Cameroon through the CAR to Sudan. Detailed structural studies in the northern part of this study area [27] show that the mylonites follow an intricate conjugate fault system with NE-SW and NNW-SSE trends. These faults truncate and deform an earlier shear system with an N120 E trend. The major lineament that crosses the Bossangoa-Bossembele region from east to west is a mylonitic band that consists of pseudotachylites, blastomylonites and granitic gneisses of the basement [28]. This basement comprises also schists, sericite schists, micaschists and amphibolites [28].

The precise ages of rock units in the study area and the timing of movements along the Pan-African structures in the CAR are unknown.

\section{PETROGRAPHY}

The basement of the Bossangoa-Bossembéle area comprises gneisses, garnet schist, amphibolite, pyroclastic rocks and meta-granitoids, all of which have been locally mylonitised (Fig. 2). Full descriptions of these basement rock types are presented elsewhere [29] and they are only summarized here. The gneisses, amphibolites and schists are high-grade, medium-grade and low-grade metamorphic rocks evidenced by the $\mathrm{Cpx}+\mathrm{Opx}+\mathrm{Pl}+\mathrm{Qtz}+\mathrm{Kfs}$ and Sill + $\mathrm{Grt}+\mathrm{Qtz}+\mathrm{Kfs}+\mathrm{Pl}+\mathrm{Gr}+\mathrm{Ru}$ (gneisses), $\mathrm{Qtz}+\mathrm{Kfs}+\mathrm{Pl}+$ $\mathrm{Hbl}+\mathrm{Grt}+\mathrm{Op}$ (amphibolites), Ms + Grt +Qtz +Kfs and Bt $+\mathrm{Ms}+\mathrm{Ep}+\mathrm{Op}$ (schists) mineral associations (abbreviation after Kretz [30]). The gneisses have distinct mineralogical layering consisting of alternating bands of quartz and 


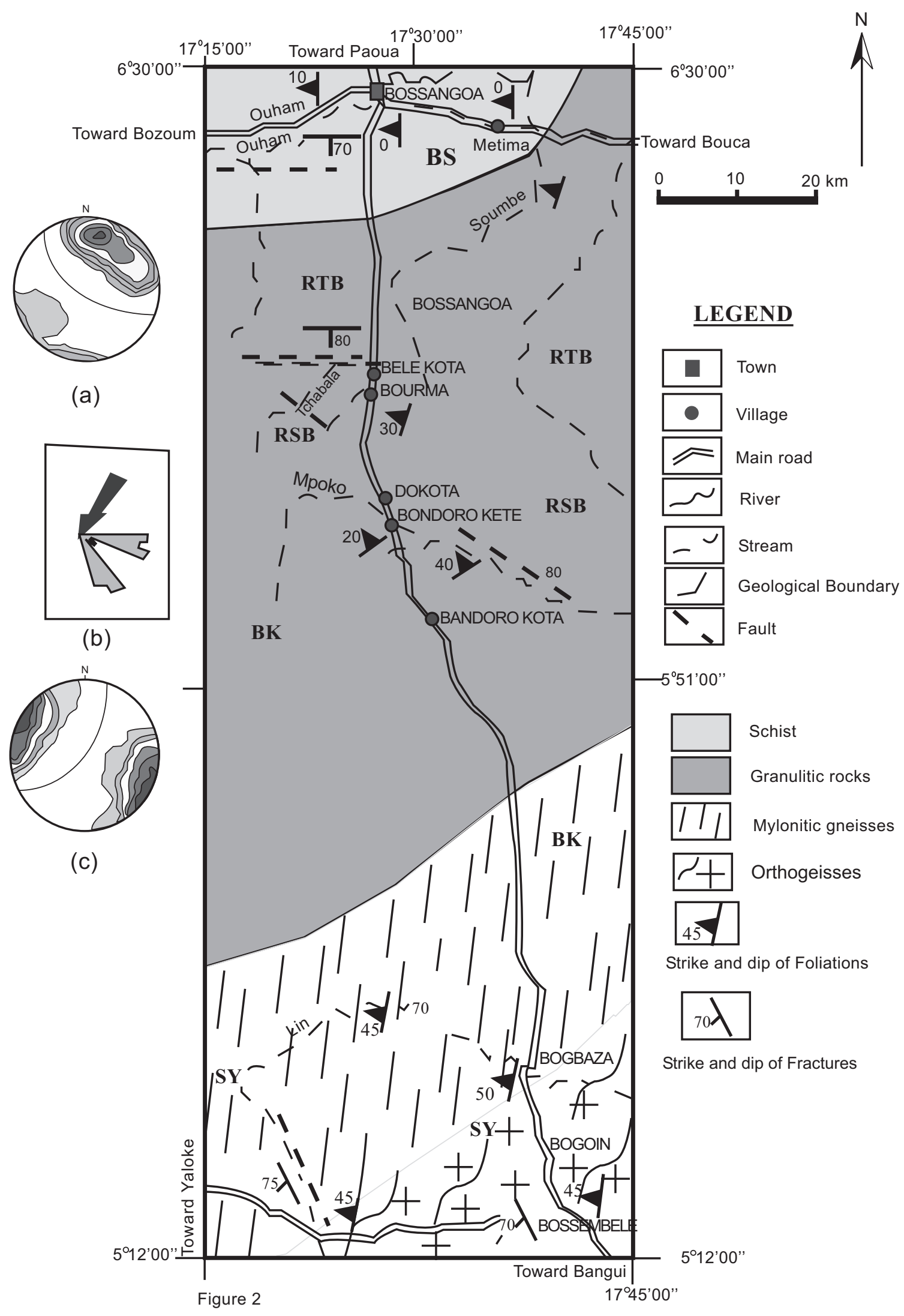

Fig. (2). Structural and geologic map of the study area. Inset: (a) density stereoplot of pole foliations (Schmidt lower hemisphere projection), (b) rose diagram (black-foliations; grey-fractures) and (c) density stereoplot fracture surfaces (Schmidt lower hemisphere projection) showing major structural trends. 
feldspar grains of variable sizes and pyroxene-dominated bands. The meta-granites are foliated (Fig. 3) and have the following deformation characteristics at the microscopic scale: undulatory extinction and kink bands in quartz, formation of myrmekites at the expense of alkali feldspar, kink and deformation twins in plagioclase and development of secondary biotite. The mylonitized rocks (Fig. 3a) have sheared and stretched quartz ribbons with an anastomosing pattern of intervening lenses of less deformed gneiss and schist. The quartz ribbons and a retrograde mineral association comprising hornblende, muscovite, epidote, oxides and biotite define mineral lineation in the mylonitized rocks.
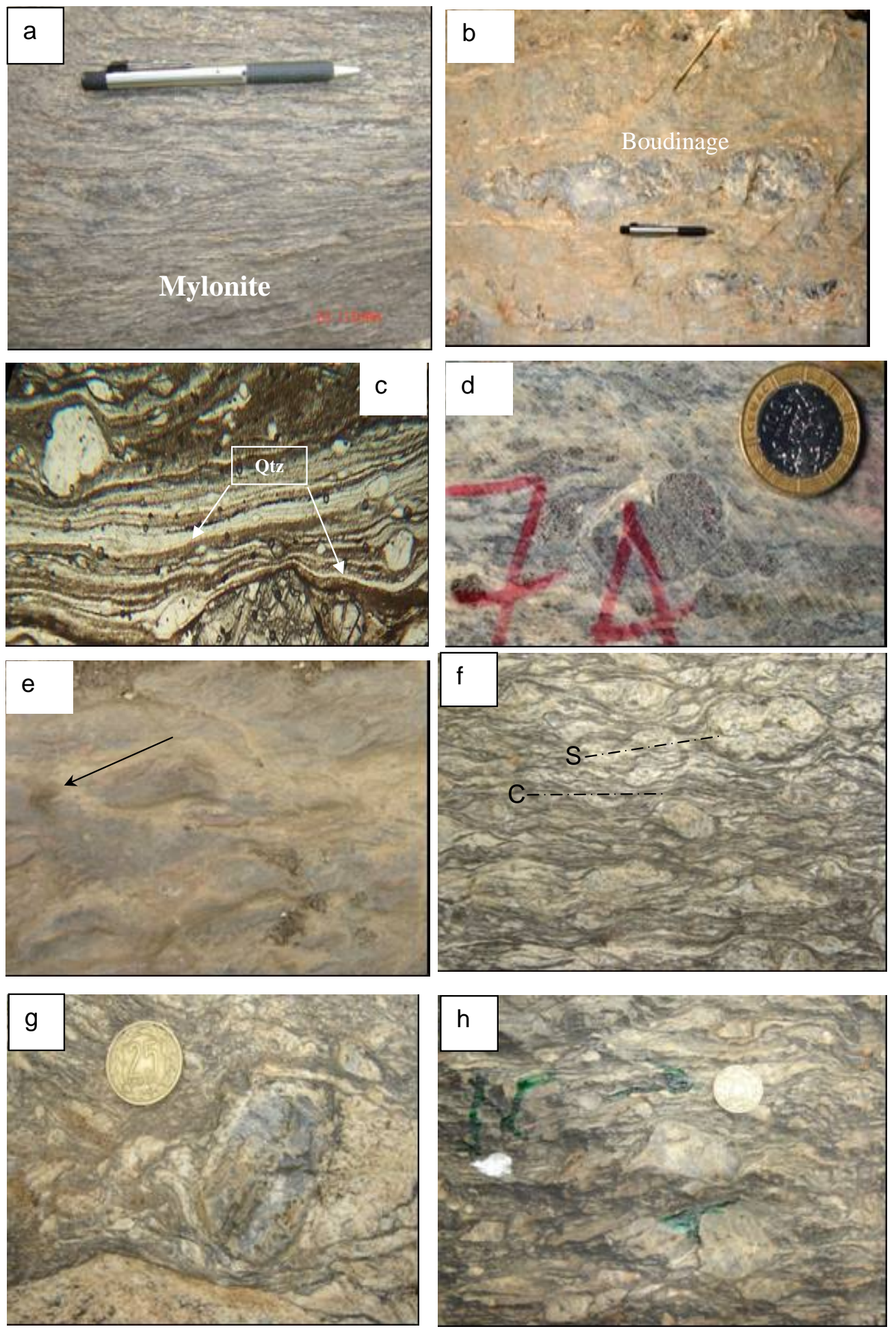

Fig. (3). Shear Zone fabric. (a) Mylonite (garnet-sillimanite gneisses) showing gently to moderately dipping foliation; (b) boudinage; (c) quartz crystal showing plastic deformation; (d) and (e) asymmetric protolith boudins. Foliated meta-granitoids: (f) C-S fabrics; macroscopic sinistral shear indicators such as $(\mathbf{g}) \delta$-structures and, (h) $\sigma$-structures. 


\section{MESOSTRUCTURAL DATA AND INTERPRETATION}

\subsection{Shear Zone Fabric}

The Bossangoa-Bossembéle Shear Zone is defined by gently to moderately dipping foliation (Fig. 3a, 5) bearing a well-developed subhorizontal mineral-stretching lineation. Evidence of stretching parallel to the lineation is widespread throughout the entire shear zone, especially boudinage (Fig. 3b) and extensional faulting of layers or dykes of more competent rocks, recrystallization tails on feldspars, elongated enclaves in mylonitized magmatic rocks, and pressure shadows on synkinematic garnet porphyroblasts. This lineation is usually defined by metamorphic minerals like sillimanite, amphibole, and biotite, which grew parallel to the stretching direction.

Shear zones in the Bossangoa-Bossembéle area are defined by a well-developed mylonite zone in which both high- and low- temperature mylonites coexist. Hightemperature mylonites were derived from various kinds of pre-existing rocks: metasedimentary rocks, metabasites and pre- to synkinematic intrusive rocks. In the high-temperature mylonites a continuous transition from magmatic to solidstate flow is marked by: (a) microfractures filled with quartz and feldspar in K-feldspar porphyroclasts, suggesting formation due to stress concentrations at contacts between grains in the submagmatic stage [31,32]; (b) crystal plastic deformation (Fig. 3c) and dynamic recrystallization of plagioclase, myrmekite growth along the boundaries of Kfeldspar porphyroclasts, indicating that ductile deformation occurred under high-temperature [33,34]. Shear criteria are abundant and a large variety of kinematic indicators have been observed (e.g. Fig. 3d, e). Undeformed and asymmetric protolith boudins (Fig. 3d, e), commonly elongate parallel to the mineral lineation, are good shear sense indicators and define an overall sinistral sense of shear. At the boundaries of the shear zone, the gneissose layering is deformed into small-scale drag folds that show a sinistral sense of displacement. The sinistral sense of movement along the shear plane was also deduced from displacement of quartz veins, some of which show rotational movement. Within the ductile shear zone, the gneissose layering is rotated parallel to the mylonitic foliation. The fact that the ductile shear zone cuts across the gneissose layering and the presence of drag folds suggest that mylonitisation followed the metamorphic layering. Other macroscopic and microscopic non-coaxial sinistral shear sense indicators observed included rotated quartz pressure shadows in a muscovite matrix, C-S fabrics (Fig. 3f), $\delta$-structures (Fig. 3g) and, $\sigma$-structures (Fig. 3h).

\subsection{Foliation and Related Features}

The main planar structures are foliations and fractures (Figs. 3a, c, 5, 7). A total of 98 foliation surfaces were measured during the fieldwork. The foliation surfaces have low to moderate dips $\left(0^{\circ}\right.$ to $\left.45^{\circ}\right)$ predominantly to the west. These data, plotted on stereonets ( $\beta$-diagrams and $\pi$ diagrams) show that most of the foliations planes have a NESW trend (Fig. 5). To get an overall orientation of the foliations, the poles of these planes have been plotted and contoured (Fig. 7) using conventional techniques [35, 36]. These density plots show the poles of the foliations are
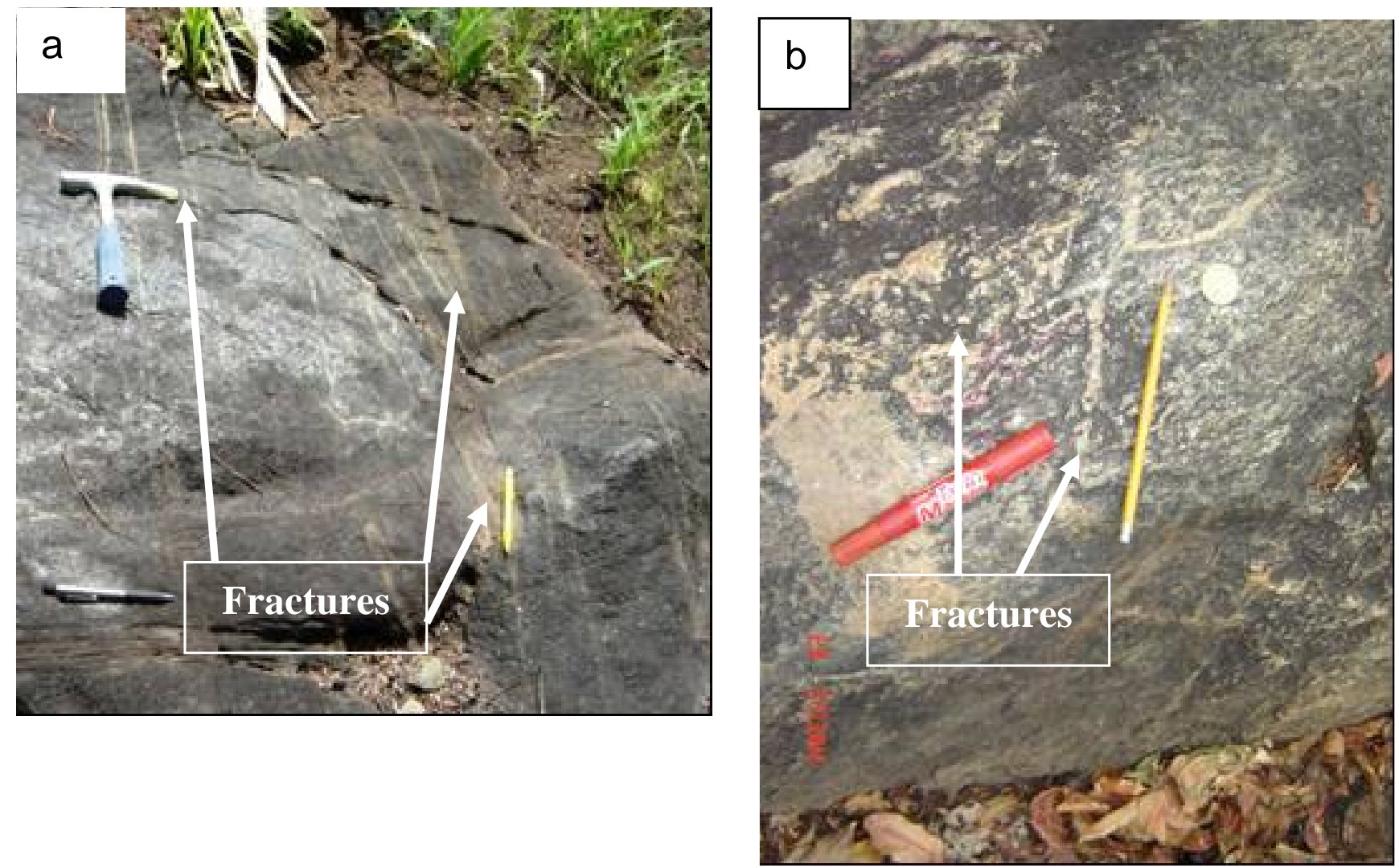

Fig. (4). (a) and (b) Fracture planes truncate the ductile foliation. 

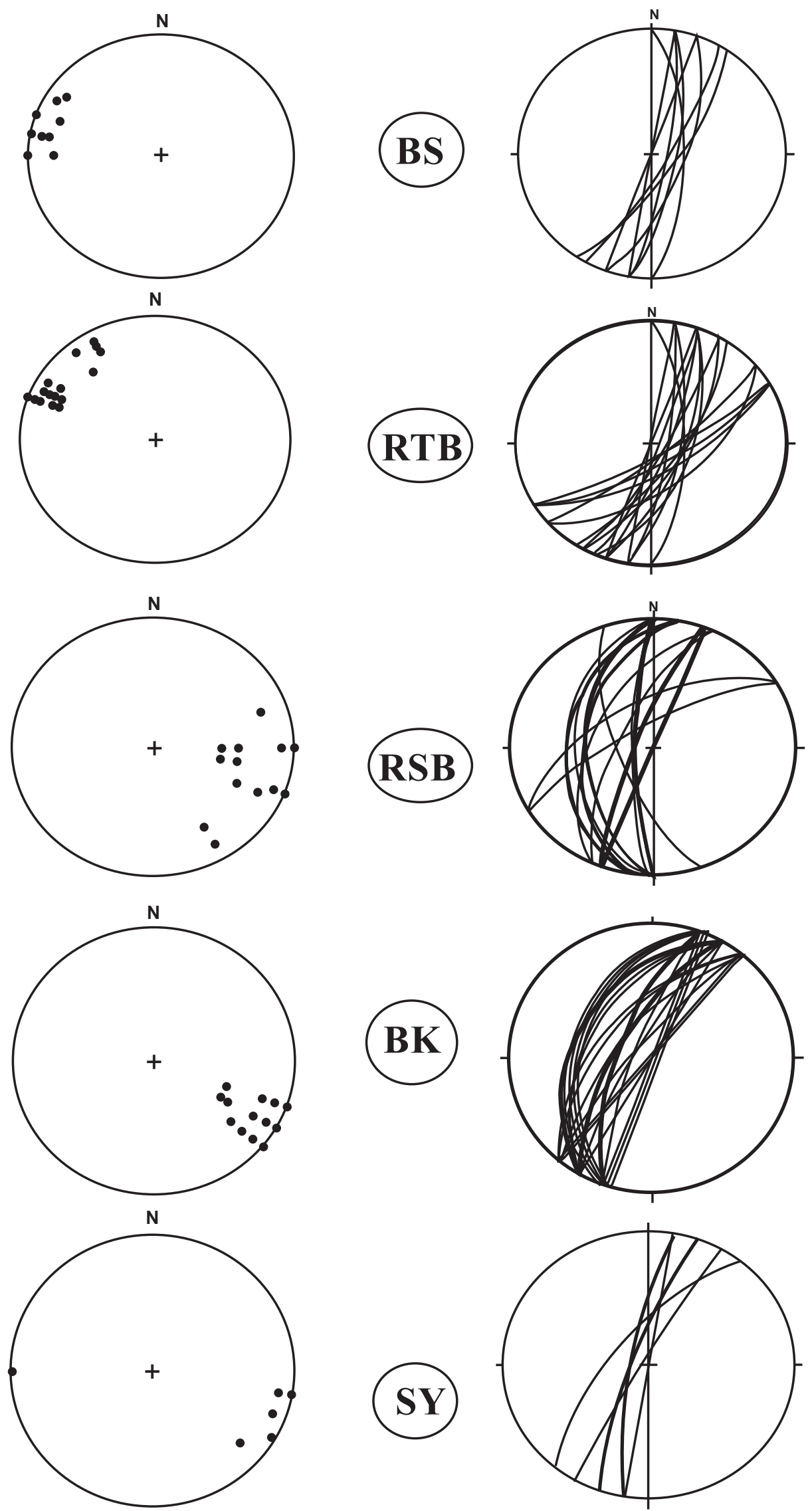

Fig. (5). Wulff net lower hemisphere stereoplots (B-diagrams) of foliation planes. Beside each plot is an equal-area lower hemisphere (Schmidt net) stereographic projection of poles ( $\pi$-diagrams) to the foliations. BS-SY refer to locations on Fig. (2). 


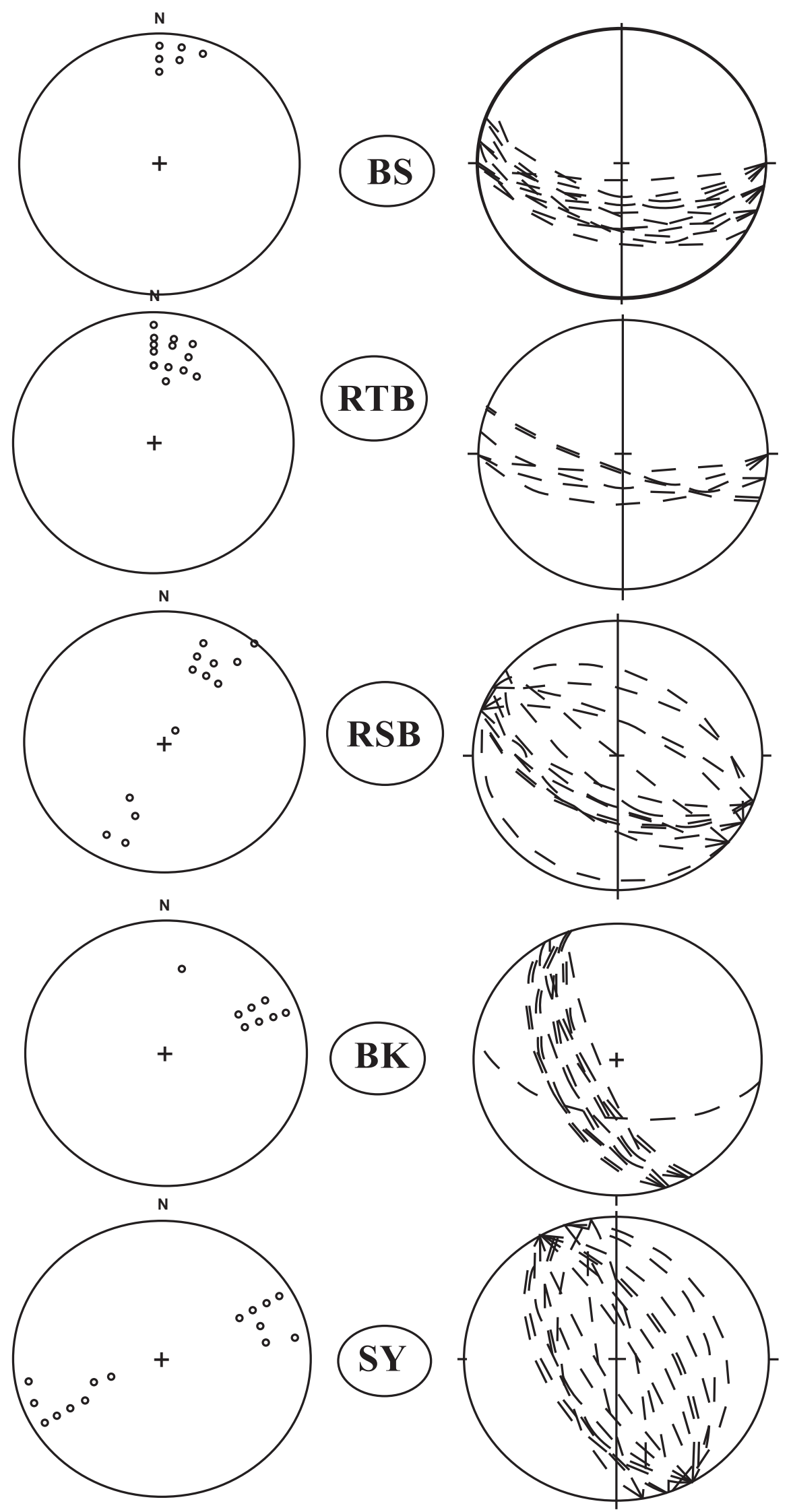

Fig. (6). Wulff net lower hemisphere stereoplots (ß-diagrams) of fracture surfaces. Beside each plot is an equal-area lower hemisphere (Schmidt net) stereographic projection of poles ( $\pi$-diagrams) to the fractures. BS-SY refer to locations on Fig. (2). 
concentrated in the NW and SE portions of the net (Fig. 7a), confirming the dominantly NE-SW trend. In order to get the specific orientation of the foliations, we constructed rose diagrams for each of the locations from which measurements were taken (Fig. 8). These rose diagrams define two dominant directions for foliations: NE-SW (locations RTB, RSB, and BK) and N-S (locations BS and SY). Fig. (8) also shows form lines drawn on the basis of the raw structural data and rose diagram plots. With respect to the foliations, these lines show a sigmoidal structural form due to the superposition of the sinistral ductile shear zone on the N-Strending gneissic layering. The predominant foliation is a mylonitic foliation (Figs. 5, 7a) that is parallel to the regional CCSZ strike-slip fault system. The foliation plane (Fig. 3a, d, e) is defined by biotite and graphite flakes, sillimanite prisms, platy quartz and rutile needles (gneisses) and by the orientation of deformed quartz grains and by mica flakes wrapping around well-preserved feldspar porphyroclasts (meta-granites). The lineation develops preferentially on the shear planes, which commonly nucleate along the edges of the K-feldspar porphyroclasts. Aggregates of quartz grains within the meta-granites also show an elongation parallel to the lineation, consistent with it being a stretching lineation. The sinistral sense of movement deduced from the mesostructures and microstructures described above, most of which show rotational movement, confirm that deformation along the mylonitic trend was non-coaxial. The original gneissic layering had an N-S trend and this was later distorted by the sinistral shearing during the mylonitisation event. This effect is discernable in Fig. (8) and on the rose diagram in Fig. (9).

\subsection{Fractures}

A total of 230 measurements of dips and strikes of fracture surfaces (Figs. 4, 6) were taken during the fieldwork. To get an overall orientation of the fractures, the poles of these planes have been plotted and contoured (Figs. 6-8) using conventional techniques $[35,36]$. These density plots show the poles of the fractures are concentrated in the NE and SW sectors (Fig. 9b), confirming the dominantly NW-SE trend of the fractures. In order to get the specific orientation of the fractures, we constructed rose diagrams for the locations from which measurements were taken (Figs. 8, 9). Rose diagrams for fractures define more or less E-W and NW-SE trends. This brittle deformation is marked by three principal sets of fractures: N150-160E, N130-140E and N090-120E. Many fractures showing only minor displacement cut the mylonites and represent the final movements on the zone. Fracture plane are usually filled by aplites and quartz veins. Some microfaults were also observed, especially in mylonitic samples that contained a significant proportion of randomly -oriented, iron-filled fractures. Field relations indicate that these fractures truncate the ductile foliation (Fig. 4). Microscopic observations show breakage of grains, particularly common with brittle feldspar. Typically, smaller fragments are smeared out along shear plane to form trails while the parent grains develop undulatory extinction and become elongate due to microfracturing. For example, the fine-grained material around these fragments has flowed in to fill the gaps between the broken fragments. This assemblage of fragmental feldspar porphyroclasts and fine-grained envelopes produce a pressure shadow-type microstructure. Microfracturing is a common phenomenon found in most of the thin sections. It occurs either within a single porphyroclast (intragranular fracturing) or cuts across many crystals in the rock.

\section{DISCUSSION}

The Bossangoa-Bossembélé rocks were deformed during two main tectonic events:

1. A $020-060^{\circ}$ trending, ductile mylonite sinistral strikeslip foliation. The mylonitisation event reworked an older $000-020^{\circ}(\mathrm{N}-\mathrm{S})$ granulitic foliation. The age of the granulite layering is uncertain. Although zircon grains from metamorphic rocks farther west along the CCSZ and south of the study area have been dated at $2100 \mathrm{Ma}$ [18, 37, 38], similar work has not been done around the BossangoaBossembelé area. Pan-African ages (618-650 Ma) have been obtained for mylonitised rocks in the western part of the CCSZ [8, 38, 39] and in NE-SW-trending ductile shear zones in Adamaoua, just west of the study area [10]. The similarity between these dated mylonites and the ones we have described around the Bossangoa-Bossembelé area allow us to constrain the age of mylonitization event as PanAfrican. The mylonites have a distinct amphibolite and greenschist facies assemblages with the appearance of hbl + $\mathrm{bt}+\mathrm{qtz}$, ep $+\mathrm{chl}+\mathrm{ser}$, and the silicification of the matrix. The hornblende, biotite and sericite in the mylonites formed from the breakdown of pyroxene and feldspars in the precursor rocks and points to the fact that mylonitisation was accompanied by fluid infiltration resulting in retrograde metamorphism.

2. A younger brittle event marked by three principal sets of fractures: $\mathrm{N} 150-160^{\circ} \mathrm{E}, \mathrm{N} 130-140^{\circ} \mathrm{E}$ and $090-120^{\circ} \mathrm{E}$. On a regional scale, similar brittle features that post-date ductile shearing have been documented in the adjacent Pan-African Banyo and Tombel basement in Cameroon [9, 37] and Cretaceous Benue Trough sedimentary basin in Nigeria [40]. These fractures often have volcanic or granitic veins and are believed to mark the early stages of the opening of the basin.

The tectonic evolution in the Bossangoa-Bossembelé segment of CCSZ system commenced with ductile deformation and terminated with brittle deformation. This is a classical feature of ductile shear zones that was subsequently overprinted by a brittle event $[8,33,41,42]$, although shear zones in which macroscopically brittle deformation predates a ductile event have also been described (see [43] and references therein).

Fig. (10) is a cumulative rose diagram showing foliation and fracture directions obtained in this study compared with that of Mbedo (2006) [44] for the southern part of the CAR. These results are similar to those obtained from this study, Mbedo (2006) [45] reported a $030-060^{\circ}$ - trending mylonitic foliation within orthogneiss. Despite the distance, the important NE-SW direction is clearly established from CAR and adjacent areas. This is a significant contribution to the tectonics of this region. 

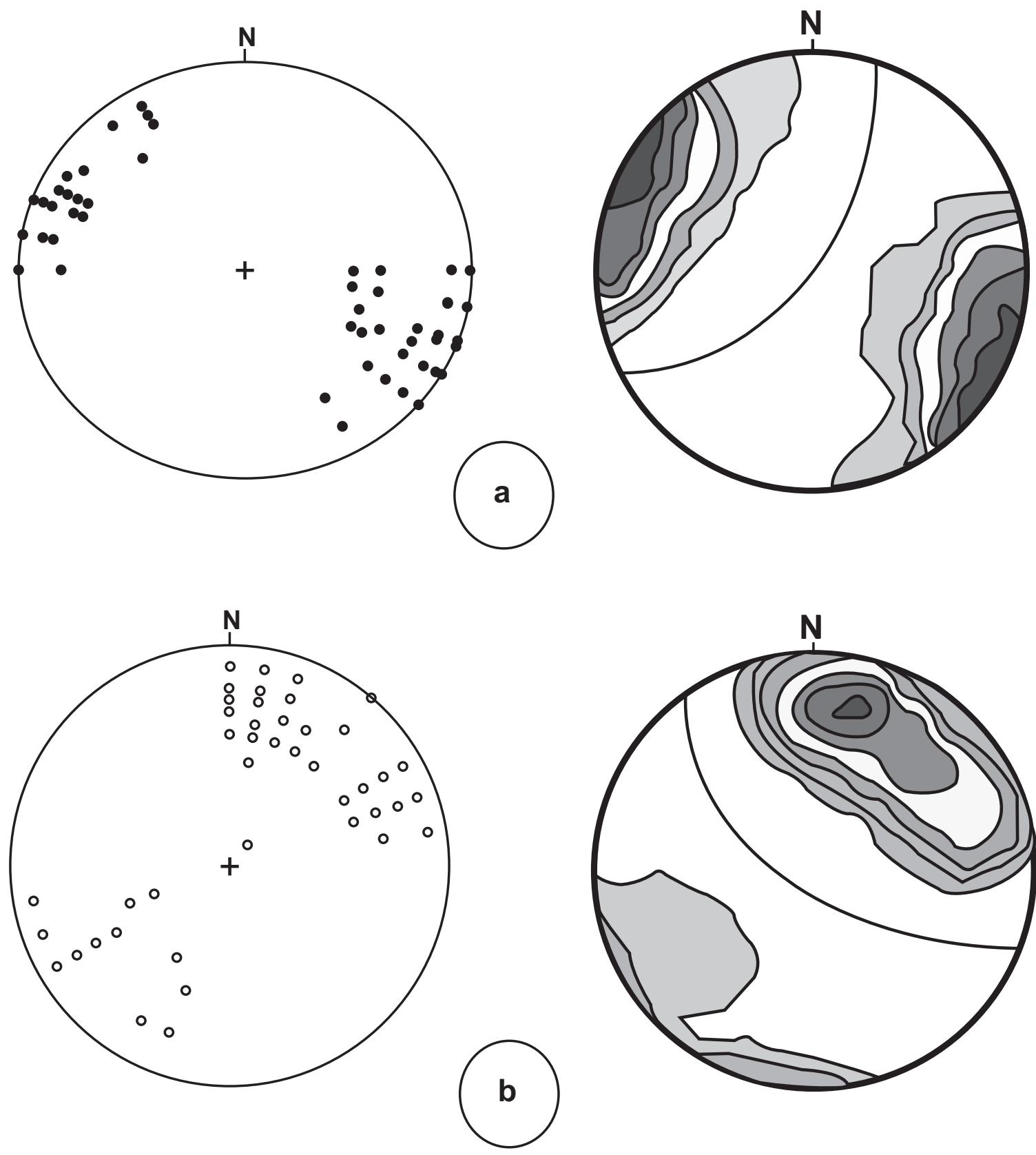

Fig. (7). a) Equal-area lower hemisphere stereographic projection of poles to foliations and density stereoplot (Schmidt lower hemisphere projection) for 98 points showing concentrations in the NW and SE portions ( NE-SW trend). Contours 2-4-6-8-10-12\% per 1\%area, maximum-16\%). b) Equal-area lower hemisphere stereographic projection of poles to fracture surfaces and density stereoplot (Schmidt lower hemisphere projection) for 230 points showing concentrations in the NE/NNE and SW/SSW portions (NW-SE trend), Contours 2-4-6-8-10$12-14 \%$ per $1 \%$ area, maximum- $20 \%$.

\section{CONCLUSION}

In this study, we have produced a structural and geological map of the northwestern part of the CAR (Fig. 2). We have also deduced for the first time, a major sinistral shear zone in the region, mainly from the orientation of mylonitic bands and subsequent deformation. We also conclude that the brittle deformation is younger than the foliations and that the region experienced a ductile to brittle transition and non-coaxial deformation. These results contribute to the better understanding of this northwestern part of the CAR in relation to the deformation and plutonism. The Bossangoa-Bossembelé shear zone is shown 


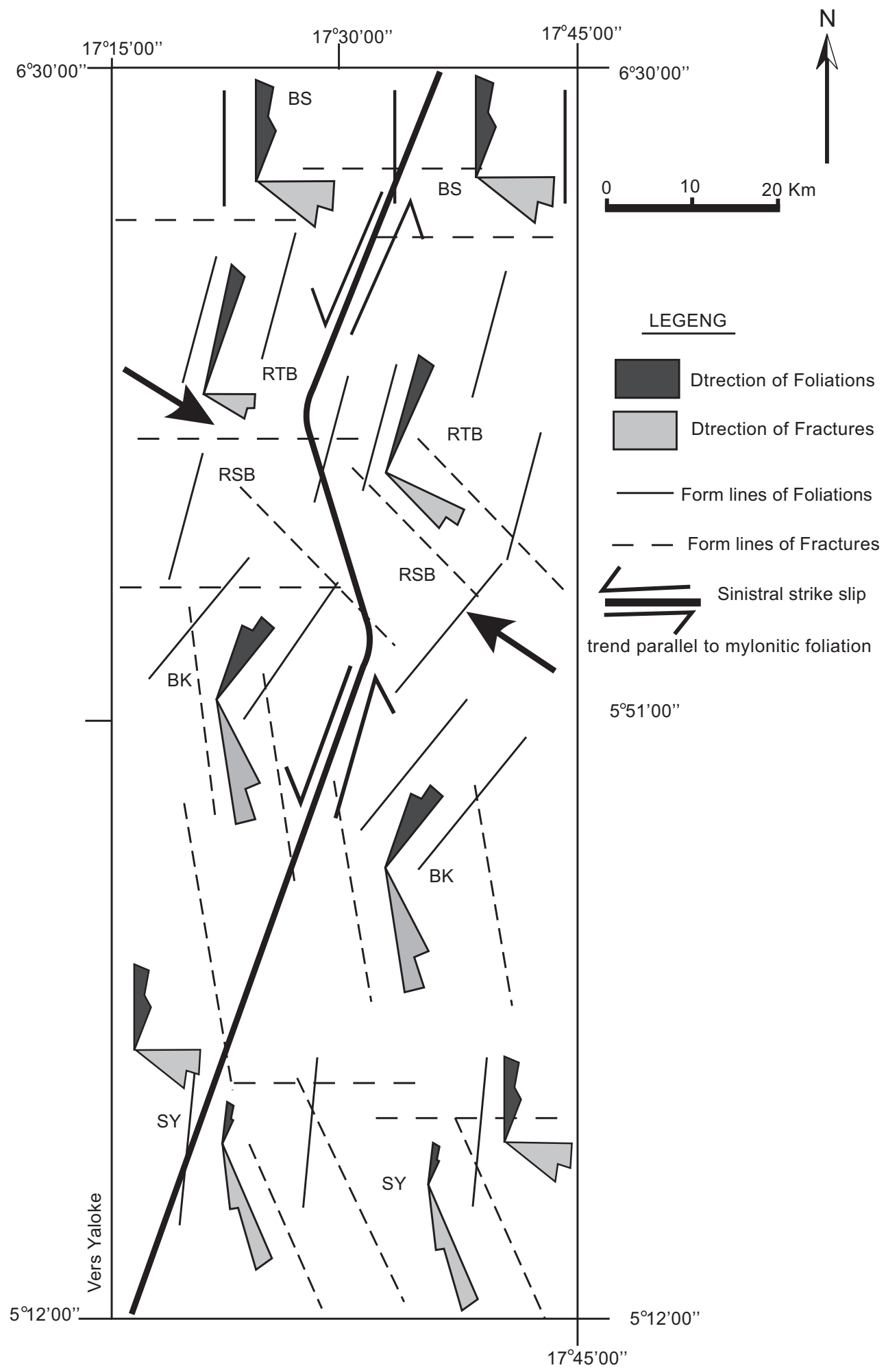

Fig. (8). Rose diagrams (for geologic map shown on Fig. 2) showing main concentrations for foliations and fractures in each locations of the study area (BS, RTB, RSB, BK and SY), and form lines drawn on the basis of these rose diagrams. ( $\sigma 1$ is deduced from conjugate fractures). Foliations poles stereoplot (Schmidt lower hemisphere projection) in the left side and fracture surfaces poles stereoplot (Schmidt lower hemisphere projection) in the right.

in paleogeographic reconstructions continuing into $\mathrm{NE}$ Brazil as the Pernambuco lineament and into Africa as the Cameroon Central Shear Zone (Fig. 1) system [4, 10, 45-48], in which case it would be comparable to the largest shear zones in the world, with an original total length well over $1000 \mathrm{~km}$. 


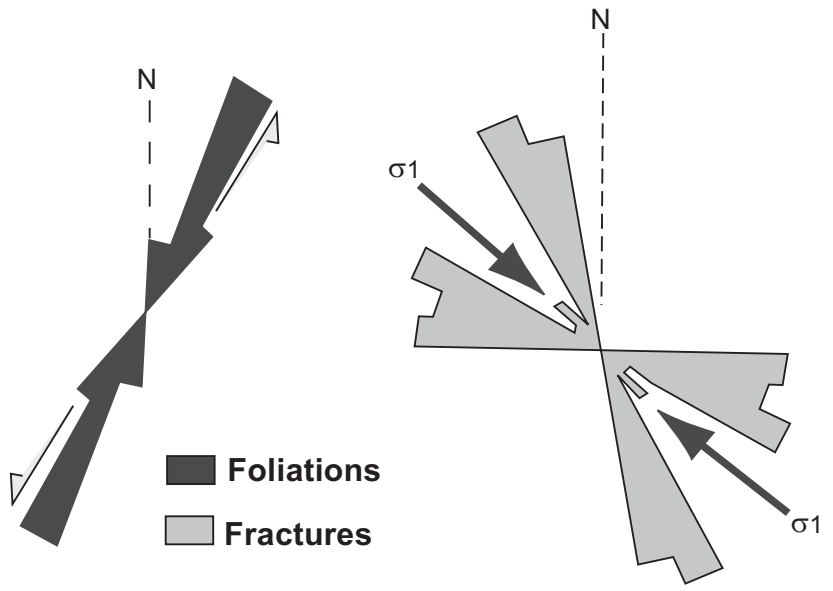

Fig. (9). Cumulative rose diagram of foliation planes (a)-depicting two main structural trends $\left(\mathrm{N} 020-060^{\circ} \mathrm{E}\right.$ and $\left.\mathrm{N} 000-020^{\circ} \mathrm{E}\right)$ and of fracture surfaces, (b)-depicting three main structural trends (N090$120^{\circ} \mathrm{E}, \mathrm{N} 150-160^{\circ} \mathrm{E}$ and $\left.\mathrm{N} 130-140^{\circ} \mathrm{E}\right)$.

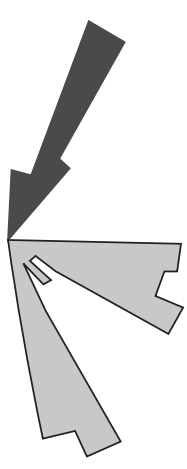

(a)

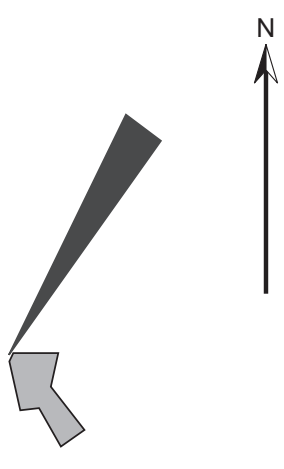

(b)

Foliations

Fractures
Fig. (10). Cumulative rose diagram for lineaments of the northwestern Central African Republic (a-this study) and southern part of the CAR (b-after [45]).

\section{ACKNOWLEDGEMENTS}

The data presented here form a part of Ph.D. thesis supervised by J.P Nzenti. The authors acknowledge financial support of AUF (Agence Universitaire de la Francophonie) and support from colleagues at University of Bangui. The comments of Professor O. R. Greiling (University of Frankfurt-Germany) and two anonymous journal reviewers are greatly appreciated.

\section{REFERENCES}

[1] R. Caby, A.N. Sial, M. Arthaud, and A. Vauchez, "Crustal evolution and the Brasiliano orogeny in northeast Brazil. in: Dallmeyer and Lécorché (Eds.): The west Afican orogens and circum-Atlantic correlatives", Springer-Verlag, 373-397, 1991.

[2] V. Ngako, P. Jegouzo, and J.P. Nzenti, "Le Cisaillement Centre Camerounais. Rôle structural et géodynamique dans l'orogenèse panAficaine", C. R. Acad. Sci. Paris, vol. 313, pp. 457-463, 1991.

[3] B.B. Brito Neves, W.R. Van Schmus, and A. Fetter, "Northwestern Afica-North eastern Brazil: major tectonic links and correlation problems", J. Afr. Earth Sci., vol. 34, pp. 275-278, 2002.
[4]

$[5]$

[6]

R. Caby, "Precamb. terranes of Benin-Nigeria and northeast Brazil and the late Proterozoic south Atlantic fit", Geol. Soc. Am., special paper 230, pp. 145-158, 1989.

U.G. Cordani, M.S. D’Agrella-Filho, B.B. Brito-Neves, and R.I.F. Trindale, "Tearing up Rodinia: the Neoproterozoic palaeogeography of South American cratonic fragments", Terra Nova, vol. 15, pp. 350-359, 2003.

E. Ferré, G. Gleizes, and J.L. Bouchez, "Internal fabric and strikeslip emplacement of the Pan-Afican granite of Solli Hills, northeast Nigeria", Tectonics, vol. 14, pp. 1205-1219, 1995.

I. Davison, and R. Alvez Dos Santos, "Tectonic evolution of the Sergipano fold belt, NE Brazil, during the brasiliano orogeny", Precamb. Res., vol. 45, pp. 319-342, 1989.

T.C. Nguiessi, J.P. Nzenti, E.N. Nsifa, P. Tempier, and F.M. Tchoua, "Les granitoïdes calco-alcalins, syn-cisaillement de Bandja dans la chaîne panAficaine nord-équatoriale au Cameroun", C.R. Acad. Sci. Paris, vol. 325, pp. 95-101, 1997.

M.S. Njome, and C.E. Suh, "Tectonic evolution of the Tombel graben basement, southwestern Cameroon", Episodes, vol. 28, pp. 37-41, 2005.

J.P. Nzenti, B. Kapajika, G. Wörner, and R.T. Lubala "Synkinematic emplacement of granitoids in a Pan-Afican shear zone in Central Cameroon", J. Afr. Earth Sci., vol. 45, pp. 74-86, 2006.

W.R. Van Schmus, B.B. Brito Neves, P.C. Hacspacher and M. Babinski, "U-Pb and Sm-Nd geochronologic studies of the eastern Borborema Province, north eastern Brazil: initial conclusions", $J$. South Am. Earth Sci., vol. 8, pp. 247-266, 1995.

J.P. Nzenti, "Prograde and retrograde garnet zoning at high pressure and temperature in metapelitic and grenatite rocks from Yaoundé”, J. Afr. Earth Sci., vol. 15, pp. 73 -79, 1992.

V. Ngako, P. Affaton, J.M. Nnange, and T. Njanko, "Pan-Afican tectonic evolution in central and southern cameroon : transpression and transtension during sinistral shear movements", J. Afr. Earth Sci., vol. 36, pp. 207-214, 2003.

M. Cornacchia, L. Giorgi, C. Caruba, and G. Vivrier, "Existence d'une zone de suture sur la marge Nord du craton congolais (secteur de Bangui, centre de la République CentrAficaine) ", C.R. Acad. Sci., Paris, vol. 308, pp. 107-110, 1989.

J. Lavreau, J.L. Poidevin, D. Ledent, J.P. Liegeois and D. Weis, (1990): "Contribution to the geochronology of the basement of Central Afican Republic", J. Afr. Earth Sci., vol. 11, pp. 69-82, 1990.

J. Lavreau, "The Archaen and lower Proterozoic of Central Afica". Brasil Geociencas, vol. 12, pp. 187-192, 1982.

7] J.P. Nzenti, P. Barbey, and F.M. Tchoua, "Evolution crustale au Cameroun: éléments pour un modèle géodynamique de l'orogenèse néoprotérozoïque". In: Vicat, J. P. \& Bilong, P. Eds., Géologie et environnements au Cameroun. Collection GEOCAM, 1999, pp. 397-407.

[18] C. Pin, and J.L. Poidevin, "U-Pb Zircon evidence or Pan-Afican granulite facies metamorphism in Central Afican Republic. A new interpretation of the high-grade series of the northern border of the Congo craton", Precamb. Res., vol. 36, pp. 302-312, 1987.

[19] J.L. Poidevin, "Données nouvelles sur le complexe amphibolitique de l'Ouham (RCA)". $11^{e}$ RAST, Clermont-Ferrand, Résumé, 1986, pp. 146.

[20] J.L. Poidevin, C. Pin, "2Ga U-Pb Zircon dating of Mbi granodiorite (Central Afican Republic (Equatorial Afica)", Precamb. Res., vol. 16, pp.157-170, 1986.

[21] J.L. Poidevin, J. Dostal and C. Dupuis, "Archaean greenstone belt from the Central Afican Republic (Equatorial Afica)", Precamb. Res., vol.16, pp. 157-170, 1981.

[22] P. Rolin, "Présence d'un chevauchement ductile majeur d'âge panAficain dans la partie centrale de la République centrAficaine. Résultats préliminaires", C. R. Acad. Sci. Paris, vol. 315, pp. 467470, 1992.

[23] J.L. Poidevin, "Les ceintures des roches vertes de la République centrAficaine (Mbomou, Bandas, Boufoyo, Bogoin) ". Thèse Doctorat de l'Université Blaise Pascal (Clermont-Ferrand II), 1991, pp. 440.

[24] M. Cornacchia, and L. Giorgi, "Discordances majeures et magmatisme des séries précambriennes de la région de Bogoin. (Centre Ouest de la Republique centrAficaine)", J. Afr. Earth Sci., vol. 9, pp. 221-226, 1989. 
[25] J.L. Poidevin, "Le protérozoïque supérieur de la République CentrAficaine", Ann. Sci. Géol., Musée d'Histoire Naturelle, Bruxelles, vol. 91, pp. 1-75, 1985.

[26] M. Cornacchia, "Les failles du Nord de la Republique CentrAficaine (conséquences tectoniques) Recherches Géologiques $A f$, vol. 5, pp. 76-80, 1980.

[27] M. Cornacchia, and R. Dars, "Un trait structural majeur du continent Aficain. Les linéaments centrAficains du Cameroun au Golfe d'Aden", Bull. Soc. Géol. France, XIV-1, pp. 101-109, 1983.

[28] J. Gérard, "Notice Explicative sur la feuille Bossangoa-Est, Carte Géologique de reconnaissance à l'échelle du 1/500 000", Direction des Mines et de la Géologie de RCA, pp. 1-61, 1963.

[29] H. Mapoka, "Tectonic evolution of the Bossembele area, CentralNorthern part of CAR", M. Phil thesis; Department of Earth Sciences, University of Yaoundé I, Cameroon (unpublished), pp. 51, 2006.

[30] R. Kretz, "Symbols for rock-forming minerals", Am. Miner., vol. 68, pp. 277-279. 1983.

[31] J.L. Bouchez, C. Délas, G. Gleizes, and A. Nédélec, "Submagmatic microfractures in granites", Geology, vol. 20, pp. 35-38, 1992.

[32] M.J. Hibbard, "Indigeneous source of late-stage dykes and veins in granitic plutons", Econ. Geol., vol. 75, pp. 410-423, 1980.

[33] C.W. Passchier, and R.A.J. Trouw, Microtectonics, Springer, Berlin, 1998, pp. 289.

[34] A. Tommasi, A. Vauchez, L.A.D. Fernandes, and C.C. Porcher, "Magma assisted strain localization in an orogen parallel transcurrent shear zone of southern Brazil", Tectonics, vol. 13, pp. 421-437, 1994.

[35] D.M. Ragan, "Structural Geology: an introduction to geometrical techniques", $2^{\text {nd }}$ ed., John Wiley and Sons, New York, 1973, pp. 1208.

[36] F.C. Phillips, "The use of stereographic projections in structural geology”, E.A. London (publishers) Ltd, pp.1-86, 1955.

[37] J.P. Nzenti, "L'Adamaoua panAficain (région de Banyo): une zone clé pour un modèle de la chaîne panAficaine nord-équatoriale au Cameroun", Thèse Doct. d'Etat, Univ Cheikh Anta Diop -Univ Nancy I, France, 1998.

[38] E.L. Tanko Njiosseu, J.P. Nzenti, T. Njanko, B. Kapajika, and A. Nédelec, "New U-Pb zircon ages from Tonga (Cameroon): coexisting Eburnean-Transamazonian (2.1 Ga) and Pan-Afican (0.6 Ga) imprints", C. R. Géosci., vol. 337, pp. 551-562, 2005.

[39] J.P. Nzenti, P. Barbey, J.M. Bertrand, and J. Macaudière, "La chaîne panAficaine au Cameroun : cherchons suture et modèle!" In: S. G. F. Ed., $15^{\text {ème }}$ Réunion des Sciences de la Terre, Nancy, France, pp. 99, 1994.

[40] J.C. Maurin, and J.R. Lancelot, "Structural setting and U-Pb dating of uranium mineralizations from the northeastern part of Nigeria (Upper Benue Region)", J. Afr. Earth Sci., vol. 10, pp. 421-433, 1990.

[41] C.W. Passchier, C.E. Ten Brink, P.D. Bons, and D. Sokoutis, "Delta-objects as a gauge for stress sensitivity of strain rate in mylonites", Earth Planet. Sci. Letts, vol. 120, pp. 239-245, 1993.

[42] C.E. Suh and S.S. Dada, "Fault rocks and differential reactivity of minerals in the Kanawa Violaine uraniferous vein, NE Nigeria", $J$. Struct. Geol., vol.19, pp. 1037-1044, 1997.

[43] J. Imber, R.E. Holdsworth, C.A. Butler and R.A. Strachan, "A reappraisal of the Sibson-Scholz fault zone model: the nature of frictional to viscous ("brittle-ductile") transition along a long-lived crustal scale fault, Outer Hebrides Scotland", Tectonics, vol. 20, pp. 601-624, 2001.

[44] B. Mbedo, "Tectono-metamorphic evolution of the Bogoin area, Central part of CAR", M.Sc. thesis, Geology Department, University of Bangui, CAR (unpublished), 2006, p. 45.

[45] J.P. Nzenti, P. Barbey, J. Macaudiere, and D. Soba, "Origin and evolution of late Precamb. high - grade Yaounde gneisses (Cameroon)", Precam. Res., vol. 38, pp. 91-109, 1988.

[46] J.M. Bertrand, and E.F. Jardim de Sà, "Where are the EburneanTransamazonian collisional belts?" Can. J. Earth Sci, vol. 27, pp. 1382-1393, 1990.

[47] C. Castaing, J.L. Feybesse, D. Thiéblemont, C. Triboulet, and P. Chèvremont, "Palaeogeographical reconstructions of the PanAfican/Brasiliano orogen: closure of an oceanic domain or intracontinental convergence between major blocks?" Precam. Res., vol. 69, pp. 327-344, 1994.

[48] S.P. Neves and G. Mariano, "Assessing the tectonic significance of a large-scale transcurrent shear zone system: the Pernambuco lineament, northeastern Brazil”, J. Struct. Geol., vol. 21, pp. 1369$1383,1999$.

(C) Mapoka et al.; Licensee Bentham Open.

This is an open access article licensed under the terms of the Creative Commons Attribution Non-Commercial License (http://creativecommons.org/licenses/by-nc/ $3.0 /$ ) which permits unrestricted, non-commercial use, distribution and reproduction in any medium, provided the work is properly cited. 